\title{
Long-Term Fluoride Release from Resin-Reinforced Orthodontic Cements Following Recharge with Fluoride Solution
}

\author{
Rogério Lacerda dos SANTOS ${ }^{1}$ \\ Matheus Melo PITHON ${ }^{1}$ \\ Delmo Santiago VAITSMAN ${ }^{2}$ \\ Mônica Tirre de Souza ARAÚJO' ${ }^{1}$ \\ Margareth Maria Gomes de SOUZA ${ }^{1}$ \\ Matilde Gonçalves da Cunha NOJIMA ${ }^{1}$ \\ ${ }^{1}$ Departament of Orthodontics, Federal University of Rio de Janeiro, Rio de Janeiro, RJ, Brazil \\ ${ }^{2}$ Departament of Chemistry, Federal University of Rio de Janeiro, Rio de Janeiro, RJ, Brazil
}

\begin{abstract}
The aim of this study was to test the hypothesis that there is no difference in the fluoride release behavior of resin-reinforced glass ionomer cements before or after fluoride recharge. The materials were divided into 5 groups: 2 resin-reinforced glass ionomer cements used for attaching orthodontic bands, that is, group FOB (Fuji Ortho Band) and group MCB (Multi-Cure Glass Ionomer Orthodontic Band Cement); 2 resin-reinforced glass ionomer cements and a composite used for bonding orthodontic brackets, that is, group OGLC (Ortho Glass LC), group FOLC (Fuji Ortho LC), and group TXT (Transbond XT), respectively. Fluoride release was measured during a 60 -day period by using selective ion electrodes connected to an ionic analyser. After 4 weeks, the samples were exposed to $0.221 \%$ sodium fluoride solution. The results showed that cements achieved a maximum fluoride release $24 \mathrm{~h}$ after initial setting. No statistically significant differences were observed between groups FOB and OGLC regarding the amount of released fluoride following fluoride recharge from day 31 to day 36 ( $>00.05$ ). In conclusion, FOB and OGLC cements showed a higher capacity of capturing and releasing fluoride compared to the other cements studied.
\end{abstract}

Key Words: glass ionomer cement, fluoride release, Orthodontics.

\section{INTRODUCTION}

Cleaning orthodontic brackets and bands represents a challenge for the patient wearing them, these attachments act as plaque-retaining structures leading demineralization of adjacent enamel (1). In order to reduce the occurrence of such demineralization processes, the orthodontic attachments should be maintained with materials which can release fluoride and provide adequate adhesion to both enamel and stainless steel (2).

In Orthodontics, white spot lesions and marginal gingivitis arise much concern among professional, who have been tackling this problem by making use of materials to decrease and prevent such damage to oral health (2), among which are the ionomer cements (GICs). Since their introduction in 1971, GIC have been employed for a number of applications mainly due its chemical adhesion to enamel, dentin and other surfaces in addition to releasing fluoride (3). The evolution of GIC properties has contributed to the decrease in dental caries among orthodontically treated patients due to the biological and chemical characteristics of this material (4).

Despite these favorable characteristics, the adhesion of brackets to dental enamel is not entirely adequate, often not being strong enough to resist to masticatory forces and orthodontic movements (5). In order to overcome this problem, manufacturers have developed hybrid products by incorporating a resin matrix system to GICs, thus combining the retentive capacity of resins with the well known beneficial properties of GICs.

Correspondence: Dra. Matilde Gonçalves da Cunha Nojima, Programa de Pós-Graduação em Odontologia (Ortodontia), Faculdade de Odontologia, Universidade Federal do Rio de Janeiro, Avenida Professor Rodolpho Paulo Rocco, 325, Ilha do Fundão, 21941-617 Rio de Janeiro, RJ, Brasil. Tel: +55-21-2590-2727. e-mail:matildenojima@uol.com.br 
These materials were denominated as resin-reinforced glass ionomer cements (RRGICs).

Fluoride release from ionomer materials that had been exposed to fluoride recharge during short periods of time, at 15-day intervals (6) or over 1-day period (7) has been demonstrated.

RRGICs can be used in Orthodontics due to their resistance to orthodontic forces, thus becoming a useful material for bonding orthodontic accessories and preserving the dental enamel. Accepting that the RRGICs analyzed in this study release fluoride and are used for bonding brackets and attaching orthodontic bands, the aim of the present investigation is to observe the behavior of RRGICs regarding pre- and post-recharge fluoride release, raising the hypothesis that there is no difference among them.

\section{MATERIAL AND METHODS}

Light-cured orthodontic materials were evaluated regarding fluoride release as follows: 2 RRGICs used for attaching orthodontic bands, group FOB (Fuji Ortho Band; GC American Corporation, Tokyo, Japan) and group MCB (Multi-Cure Glass Ionomer Orthodontic Band Cement; 3M Unitek, Monrovia, USA); 2 RRGICs and a composite used for bonding orthodontic brackets, group OGLC (Ortho Glass LC; DFL, Rio de Janeiro, RJ, Brazil), group FOLC (Fuji Ortho LC), and group TXT - control (Transbond XT, 3M Unitek), respectively. Initially, samples were made by using silicon casts measuring $4 \mathrm{~mm}$ diameter and $4 \mathrm{~mm}$ height. Each orthodontic material was inserted into one of silicone cast by means of a syringe (Centrix; DFL) in order to avoid air bubbles. The surface of the samples was covered with glass laminas by digital pressure, thus providing standardization of the materials' surface. The cements were left untouched for $10 \mathrm{~min}$. All the materials were manipulated by only one operator according to the manufacturers' instructions.

A total of 50 samples were prepared, 10 for each cement and 10 for the composite group. The samples were kept in a humidifier at $37^{\circ} \mathrm{C}$ and $100 \%$ humidity for $30 \mathrm{~min}$. After this period, 2 samples from each group were put into an identified glass container with $8 \mathrm{~mL}$ deionized water (Millipore, Bedford, MA, USA). The glass containers were put into a stove (B2C type, $\# 105)$ at $37^{\circ} \mathrm{C}$ throughout the study. The samples were slightly dried every $24 \mathrm{~h}$ by using sheets of absorbent paper, and the water in each container was replaced as well. This procedure was performed to prevent fluoride accumulation and to assess the daily fluoride release as reported by Kuvvetti et al. (8).

The $8 \mathrm{~mL}$ solution and $2 \mathrm{~mL}$ deionized water used to wash the samples were mixed and then diluted 5 times. The total ionic force (TISAB) was adjusted with $50 \mathrm{~mL}$ buffer solution. Fluoride concentrations were analyzed with a selective electrode (Thermo Orion model 9606; Orion Research Inc., Boston, MA, USA) connected to a ionic analyzer ( $\mathrm{Ph} /$ ion 450M; Analyzer, São Paulo, $\mathrm{SP}$, Brazil). The electrode was gauged every day by using standard solutions of fluoride $(0.05,0.10$, and 0.19 $\mathrm{ppm})$. The concentrations of fluoride released from each material were recorded and then converted into $\mu \mathrm{g} / \mathrm{cm}^{2}$ in order to demonstrate the amount of fluoride released per sample area unit. Fluoride release was measured at $1 \mathrm{~h}, 1,3,7,14,21$, and 28 days.

After 4 weeks, the samples were washed with deionised water for $20 \mathrm{~s}$ and their surfaces were slightly dried with disposable paper. Next, the samples were exposed to $0.221 \%$ sodium fluoride $(\mathrm{NaF})$ solution (1000 ppm of fluoride) on day 28 for 5 min and then washed with deionized water for $20 \mathrm{~s}$. Two samples were placed in a glass container with $8 \mathrm{~mL}$ deionized water, and fluoride release was measured after 24 and $48 \mathrm{~h}$ (days 29 and 30) in order to verify the release time of absorbed fluoride. From day 30 to day 36, further fluoride recharges were done as described above and assessed again after $24 \mathrm{~h}$ in order to observe the recharge capacity. Further evaluations were performed on days 45 and 60 in order to verify the post-recharge behavior of these cements after 15 and 30 days. Deionized water was used instead distilled water because the former is ion-free, and the presence of ions might mask the results $(3,9)$.

By measuring the fluoride in parts per million in a known volume of water, it was possible to calculate the total amount of fluoride ions released from the specimens. After each reading was taken, the total fluoride released in micrograms was calculated by multiplying the parts per million $(1 \mathrm{ppm}=1 \mu \mathrm{g} /$ $\mathrm{mL})$ by the water sample volume $(10 \mathrm{~mL})$. The total fluoride was then divided by the area of the sample disk to obtain the fluoride release in micrograms per square centimeter.

ANOVA with multiple comparisons and Kruskal-Wallis test were employed to assess the groups, and a significance level of 0.05 was set for identifying any statistically significant difference in fluoride release. 


\section{RESULTS}

The amount of fluoride released from each material during the study period is shown in Figure 1. The pattern of fluoride release was similar among the different materials, except for the TXT composite, with all RRGICs showing higher fluoride release on the first day and then a rapid decrease until day 14 . However, there were differences in the amount of fluoride released. Table 1 shows the amounts of fluoride released from each material following daily changes of the deionized water. From day 14 to day 28, the amount of fluoride released from the materials showed only small variations. On day 28 , prior to fluoride recharge, the amount of fluoride released from group FOB was higher than that of other materials, with statistically significant differences from groups OGLC, MCB, FOLC, and TXT $(\mathrm{p}=0.00)$.

Table 2 shows the fluoride release of each material after recharge with $\mathrm{NaF}$ solution. On day 29, the first day after fluoride recharge, it was observed statistically significant differences among all groups $(\mathrm{p}=0.00)$, except between groups MCB and FOLC $(p=0.615)$. On day 30 , corresponding to $48 \mathrm{~h}$ after the first fluoride recharge, it was also observed statistically significant differences among all groups $(\mathrm{p}=0.00)$, except between groups OGLC and MCB ( $\mathrm{p}=0.294)$, groups MCB and FOLC ( $p=0.109)$, and groups FOLC and TXT ( $p=0.241)$.

From day 30 to day 35 , further fluoride recharges

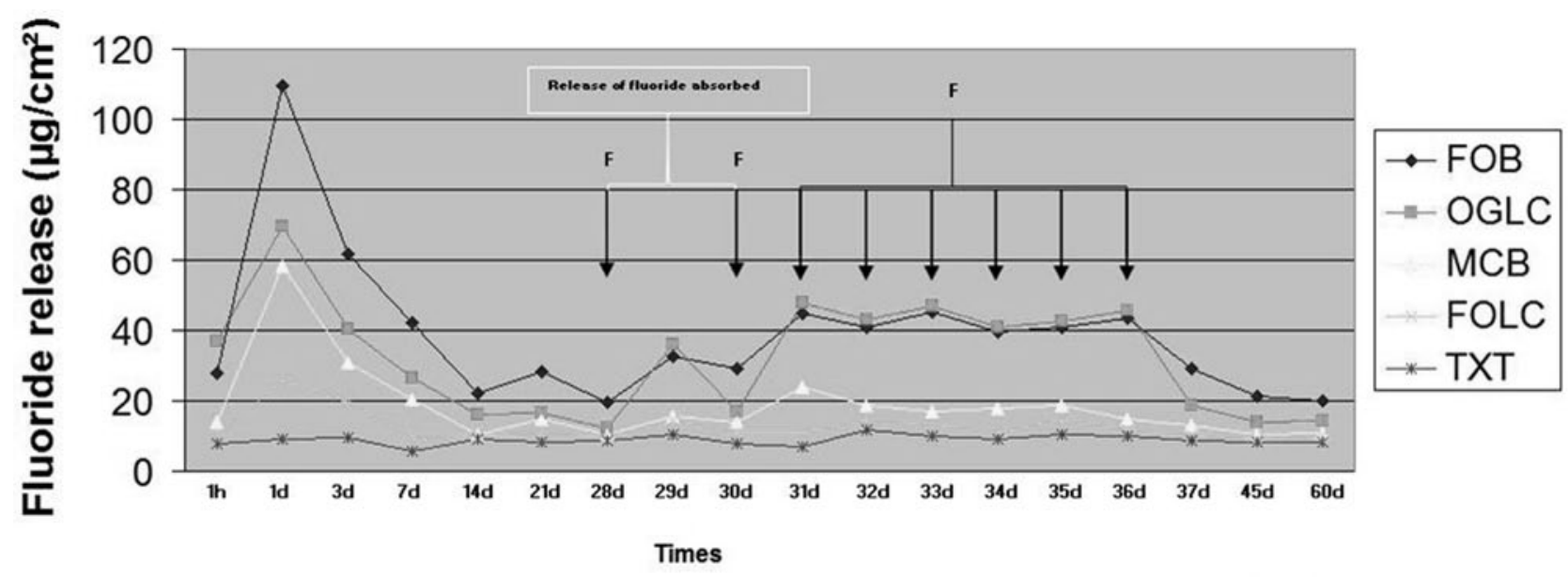

(F) Fluoride release

Figure 1. Amount of fluoride released by the materials during the experiment.

Table 1. Fluoride release from each material during 30 days (in $\mu \mathrm{g} / \mathrm{cm}^{2}$ ).

\begin{tabular}{|c|c|c|c|c|c|c|c|c|c|}
\hline Groups & $1 \mathrm{~h}$ & 1 day & 3 days & 7 days & 14 days & 21 days & 28 days & 29 days & 30 days \\
\hline FOB & $\begin{array}{l}27.94 \\
(4.04)\end{array}$ & $\begin{array}{c}109.55 \\
(4.24)\end{array}$ & $\begin{array}{l}61.94 \\
(4.77)\end{array}$ & $\begin{array}{l}42.27 \\
(4.02)\end{array}$ & $\begin{array}{l}22.05 \\
(3.31)\end{array}$ & $\begin{array}{l}28.18 \\
(4.54)\end{array}$ & $\begin{array}{l}19.58 \\
(3.12)\end{array}$ & $\begin{array}{l}32.56 \\
(2.75)\end{array}$ & $\begin{array}{l}29.21 \\
(4.22)\end{array}$ \\
\hline OGLC & $\begin{array}{c}37.02 \\
(3.31) \mathrm{a}\end{array}$ & $\begin{array}{c}69.42 \\
(3.97) a\end{array}$ & $\begin{array}{c}40.28 \\
(3.45) \mathrm{a}\end{array}$ & $\begin{array}{c}26.43 \\
(3.27) a\end{array}$ & $\begin{array}{c}15.92 \\
(1.65) a\end{array}$ & $\begin{array}{c}16.48 \\
(1.62) a\end{array}$ & $\begin{array}{c}12.10 \\
(0.33) \mathrm{a}\end{array}$ & $\begin{array}{c}35.90 \\
(3.11) \mathrm{a}\end{array}$ & $\begin{array}{c}16.79 \\
(2.30) \mathrm{a}\end{array}$ \\
\hline MCB & $\begin{array}{c}13.83 \\
(1.52) \mathrm{ab}\end{array}$ & $\begin{array}{c}58.34 \\
(2.87) \mathrm{a}\end{array}$ & $\begin{array}{c}30.77 \\
(4.35) \mathrm{ab}\end{array}$ & $\begin{array}{c}20.38 \\
(1.37) \mathrm{a}\end{array}$ & $\begin{array}{c}10.38 \\
(0.88) \mathrm{ab}\end{array}$ & $\begin{array}{c}14.99 \\
(1.23) \mathrm{a}\end{array}$ & $\begin{array}{c}10.56 \\
(0.94) \mathrm{a}\end{array}$ & $\begin{array}{c}15.59 \\
(0.91) \mathrm{ab}\end{array}$ & $\begin{array}{c}14.05 \\
(1.11) \mathrm{a}\end{array}$ \\
\hline FOLC & $\begin{array}{c}9.47 \\
(0.85) \mathrm{ab}\end{array}$ & $\begin{array}{c}26.27 \\
(3.0) \mathrm{ab}\end{array}$ & $\begin{array}{c}19.50 \\
(1.15) a b c\end{array}$ & $\begin{array}{c}9.71 \\
(0.73) \mathrm{abc}\end{array}$ & $\begin{array}{c}10.03 \\
(0.41) \mathrm{ab}\end{array}$ & $\begin{array}{c}10.50 \\
(0.62) \mathrm{abc}\end{array}$ & $\begin{array}{c}10.19 \\
(0.62) \mathrm{a}\end{array}$ & $\begin{array}{c}14.25 \\
(0.67) \mathrm{ab}\end{array}$ & $\begin{array}{c}10.66 \\
(0.67) \mathrm{ab}\end{array}$ \\
\hline TXT & $\begin{array}{c}7.96 \\
(1.52) \mathrm{ab}\end{array}$ & $\begin{array}{c}9.07 \\
(2.87) \mathrm{ab}\end{array}$ & $\begin{array}{c}9.39 \\
(4.35) \mathrm{abcd}\end{array}$ & $\begin{array}{c}5.73 \\
(1.37) a b c\end{array}$ & $\begin{array}{c}9.07 \\
(0.88) \mathrm{ab}\end{array}$ & $\begin{array}{c}8.35 \\
(1.23) \mathrm{abc}\end{array}$ & $\begin{array}{c}8.59 \\
(0.94) a b c\end{array}$ & $\begin{array}{c}10.58 \\
(0.91) \mathrm{abcd}\end{array}$ & $\begin{array}{c}7.80 \\
(1.11) \mathrm{abc}\end{array}$ \\
\hline
\end{tabular}

$\mathrm{n}=10$, Mean (standard deviation). ${ }^{\mathrm{a}}(\mathrm{p}<0.05)$ compared to Group FOB. ${ }^{\mathrm{b}}(\mathrm{p}<0.05)$ compared to Group OGLC. ${ }^{\mathrm{c}}(\mathrm{p}<0.05)$ compared to Group MCB. ${ }^{\mathrm{d}}(\mathrm{p}<0.05)$ compared to Group FOLC - statistically significant difference among the groups for the same period of time. 
were performed successively. Groups FOB and OGLC showed higher capacity for capturing and releasing fluoride, and no statistically significant difference was found between these groups ( $>>0.05$ ). Groups MCB and FOLC showed a poorer behavior in capturing and releasing fluoride compared to the materials from groups FOB and OGLC. On day 37, it was observed that group FOB had a higher fluoride release compared to group OGLC, with statistically significant difference between these groups $(p=0.00)$. After 45 and 60 days, the materials had a fluoride release similar to that seen on days 14 and 28 , which demonstrated a detectable minimum release capacity specific to each material following a higher fluoride release. TXT composite showed no capacity of capturing fluoride.

\section{DISCUSSION}

Orthodontic brackets and bands act as biofilmretaining structures, which can cause demineralization of the adjacent enamel during orthodontic treatment (1). Therefore, an effective prevention against enamel demineralization adjacent to orthodontic attachments is necessary. Fluoride release was assessed over a period of 4 weeks, including further recharge with $\mathrm{NaF}$ solution in order to observe the behavior of the materials during the period of this study, since patients wearing fixed appliances usually visit the orthodontist once a month.

It has been reported that RRGICs and other fluoride-containing materials have an anticariogenic effect compared to non-fluoridated composites (10). It was also corroborated by the present study in which
TXT composite was found to have a low fluoride release. This anticariogenic effect is crucial in the orthodontic treatment. The fluoride solution used in this study was 1000-ppm NaF, and according to Okuyama et al. (11), such a concentration was similar to that of toothpastes.

The protocol used in the present study to assess the fluoride release included daily water replacement in order to, which is better than the protocol based on fluoride accumulation (12), since, the evaluation of daily fluoride release is closer to what occurs clinically.

Caves et al. (13) have reported that type, shape, and surface area of the cement can significantly influence the fluoride release process. However, there is no standardized samples for assessment of fluoride release as stated by Creanor et al. (14). In the present study, discs of $4 \mathrm{~mm}$ diameter and $4 \mathrm{~mm}$ height were used.

The amount of fluoride released from RRGICs was higher $24 \mathrm{~h}$ after the initial setting, decreasing on days 3, 7, and 14. After the 14th day, fluoride release stabilized, as reported elsewhere $(3,8,9)$. This characteristic is clinically relevant regarding the materials used for attaching orthodontic bands and bonding brackets. RRGICs kept the fluoride release relatively stable after the 14th day, except the FOB, which had a higher fluoride release compared to OGLC, MCB, and FOLC materials. This can have a greater clinical effect on the prevention against enamel demineralization compared to other RRGICs.

Some studies have shown that part of the fluoride released from these materials is absorbed by the adjacent dental tissues, making them more resistant to secondary caries (15) in addition to reducing demineralization

Table 2. Fluoride release after recharge with sodium fluoride solution (in $\left.\mu \mathrm{g} / \mathrm{cm}^{2}\right)$.

\begin{tabular}{lccccccccc}
\hline Groups & 31 days & 32 days & 33 days & 34 days & 35 days & 36 days & 37 days & 45 days & 60 days \\
\hline \multirow{2}{*}{ FOB } & 44.82 & 40.99 & 45.06 & 39.67 & 40.66 & 43.66 & 28.98 & 21.23 & 19.99 \\
& $(4.40)$ & $(4.89)$ & $(4.01)$ & $(4.09)$ & $(4.70)$ & $(3.27)$ & $(4.83)$ & $(2.44)$ & $(2.42)$ \\
OGLC & 47.77 & 42.85 & 46.99 & 40.99 & 42.54 & 45.66 & 18.76 & 13.99 & 14.33 \\
& $(3.96)$ & $(4.32)$ & $(4.79)$ & $(2.53)$ & $(4.44)$ & $(4.31)$ & $(1.37) \mathrm{a}$ & $(1.44) \mathrm{a}$ & $(1.13) \mathrm{a}$ \\
MCB & 23.74 & 18.49 & 16.87 & 17.74 & 18.49 & 14.95 & 13.16 & 10.29 & 10.95 \\
& $(2.64) \mathrm{ab}$ & $(2.99) \mathrm{ab}$ & $(2.14) \mathrm{ab}$ & $(1.95) \mathrm{ab}$ & $(2.71) \mathrm{ab}$ & $(1.45) \mathrm{ab}$ & $(1.43) \mathrm{ab}$ & $(0.81) \mathrm{ab}$ & $(0.65) \mathrm{ab}$ \\
FOLC & 10.98 & 14.33 & 12.98 & 11.50 & 14.78 & 11.55 & 9.97 & 9.29 & 9.78 \\
& $(0.97) \mathrm{abc}$ & $(0.79) \mathrm{ab}$ & $(2.21) \mathrm{ab}$ & $(1.17) \mathrm{abc}$ & $(1.45) \mathrm{ab}$ & $(1.91) \mathrm{ab}$ & $(0.75) \mathrm{ab}$ & $(1.38) \mathrm{ab}$ & $(0.73) \mathrm{ab}$ \\
TXT & 6.76 & 11.78 & 9.78 & 9.30 & 10.56 & 9.88 & 8.77 & 8.12 & 8.07 \\
& $(2.64) \mathrm{abc}$ & $(2.99) \mathrm{abc}$ & $(2.14) \mathrm{abc}$ & $(1.95) \mathrm{abc}$ & $(2.71) \mathrm{abc}$ & $(1.45) \mathrm{abc}$ & $(1.43) \mathrm{abc}$ & $(0.81) \mathrm{abc}$ & $(0.65) \mathrm{abcd}$ \\
\hline
\end{tabular}

$\mathrm{n}=10$, Mean (standard deviation). $\mathrm{a}(\mathrm{p}<0.05)$ compared to Group FOB. $\mathrm{b}(\mathrm{p}<0.05)$ compared to Group OGLC. $\mathrm{c}(\mathrm{p}<0.05)$ compared to Group MCB. $d(p<0.05)$ compared to Group FOLC. Statistically significant difference among the groups for the same period of time. 
and increasing remineralization (16). Also, it should be emphasized that some materials have greater effect than that from other ones. Nevertheless, both the magnitude and the duration of the anticariogenic effects of fluoride depend mainly on its concentration and retention time within the oral cavity. Therefore, it is better to have fluoride being released for longer periods of time rather than the initial "burst effect" of the material (15), since the longevity of the orthodontic appliance should be taken into account.

FOB had the highest amounts of fluoride released, followed by MCB and FOLC materials, whereas TXT composite had a poor behavior, as previously reported (9). OGLC also had a better behavior compared to MCB and FOLC. Although FOLC had significantly lower fluoride release than the other three RRGICs, this process was detectable and superior to that of TXT during the whole experiment, which is crucial in the orthodontic treatment (17).

In the initial period of $24 \mathrm{~h}$, fluoride released from FOB, OGLC, MCB, and FOLC was higher than that at the first hour, thus indicating that these cements achieve maximum fluoride release within $24 \mathrm{~h}$ after the initial setting. On days 14,21 , and 28 , the cements showed a similar pattern of fluoride released. However, the values were smaller than those measured at $1 \mathrm{~h}$ as well as on days 1,3 , and 7 . This suggests that despite the low amounts of fluoride released from the 4 materials after de $14^{\text {th }}$ day, these were detectable during the whole experiment, which could also be observed on days 45 and 60 .

Itota et al. (18), observed that the amount of fluoride recharge may depend on the capacity of each material for releasing the intrinsic fluoride, since the sites containing it are set and limited. The cements presenting the highest fluoride release at the initial phase also had the highest release during the whole experiment, thus suggesting a greater recharge capacity (19). It has been shown (11), the post-recharge fluoride release tends to be similar to that observed in the initial phase, a finding that was observed during the periods for fluoride recharge (days 29 and 36).

According to Xu and Burgess (19), the porosity of the materials can have great influence on the amount of fluoride released before and after recharge. It is obvious that a greater porosity allows fluoride to be more optimally recharged, resulting in larger amounts of fluoride storage and release. As RRGICs have less porosity than the conventional GICs and greater amount of porosity than composites, RRGICs release more fluoride than composites, as reported by Cacciafesta et al. (9).

A previous in vivo study (20) has shown that brackets and bands attached with RRGICs increased significantly the fluoride concentration in saliva. However, those authors suggested to check the orthodontic bands routinely, as the fluoride released may not inhibit completely the developing carious lesions under loosen orthodontic bands or in areas with absence of cement.

It may be concluded that, for attaching orthodontic bands, FOB released more fluoride than MCB; for bonding orthodontic brackets, OGLC released more fluoride than FOLC. It is suggested mouth-rinsing with $\mathrm{NaF}$ solution in order to increase the amount of fluoride to be captured by and released from RRGICs.

\section{RESUMO}

O objetivo deste estudo foi testar a hipótese que não há diferença no desempenho dos cimentos de ionômero de vidro reforçados com resina entre si quanto à liberação de flúor antes e após recarga com flúor. Os materiais foram divididos em 5 grupos: 2 cimentos de ionômero de vidro reforçados com resina utilizados para cimentação de bandas ortodônticas: Grupo FOB (Fuji Ortho Band) e Grupo MCB (Multi-Cure Glass Ionomer Orthodontic Band Cement); 2 cimentos de ionômero de vidro reforçados com resina e 1 compósito utilizados para colagem de bráquetes ortodônticos: Grupo OGLC (Ortho Glass LC), Grupo FOLC (Fuji Ortho LC); e Grupo TXT (Transbond XT), respectivamente. A liberação de flúor foi medida durante 60 dias, através de eletrodo íon seletivo conectado a um analisador de íons. Após 4 semanas, os corpos de prova foram expostos a solução de fluoreto de sódio à $0,221 \%$. Os resultados evidenciaram que os cimentos atingiram o pico máximo de liberação de flúor com 24 h após presa inicial. Não houve diferença estatisticamente significante entre a quantidade de flúor liberado após as recargas de fluoreto de sódio entre os grupos FOB e OGLC do $31^{\circ}$ ao $36^{\circ}$ dia $(p>0.05)$. Concluindo os cimentos FOB e OGLC apresentaram maior capacidade de captação e liberação de flúor comparada aos outros CIVRRs.

\section{REFERENCES}

1. Pascotto RC, Navarro MF, Capelozza Filho L, Cury JA. In vivo effect of a resin-modified glass ionomer cement on enamel demineralization around orthodontic brackets. Am J Orthod Dentofacial Orthop 2004;125:36-41.

2. Cohen WJ, Wiltshire WA, Dawes C, Lavelle CL. Long-term in vitro fluoride release and rerelease from orthodontic bonding materials containing fluoride. Am J Orthod Dentofacial Orthop 2003; 124:571-576.

3. Komori A, Kojima I. Evaluation of a new 2-paste glass ionomer cement. Am J Orthod Dentofacial Orthop 2003;123:649-652.

4. Chatzistavrou E, Eliades T, Zinelis S, Athanasiou AE, Eliades G. Fluoride release from an orthodontic glass ionomer adhesive in vitro and enamel fluoride uptake in vivo. Am J Orthod Dentofacial Orthop 2010;137:458-459.

5. Bishara SE, Gordan VV, VonWald L, Jakobsen JR. Shear bond 
strength of composite, glass ionomer, and acidic primer adhesive systems. Am J Orthod Dentofacial Orthop 1999;115:24-28.

6. Suljak JP, Hatibovic-Kofman S. A fluoride release-adsorptionrelease system applied to fluoride-releasing restorative materials. Quintessence Int 1996;27:635-638.

7. Donly KJ, Nelson JJ. Fluoride release of restorative materials exposed to a fluoridated dentifrice. ASDC J Dent Child 1997;64:249250.

8. Kuvvetli SS, Tuna EB, Cildir SK, Sandalli N, Gencay K. Evaluation of the fluoride release from orthodontic band cements. Am J Dent 2006;19:275-278.

9. Cacciafesta V, Sfondrini MF, Tagliani P, Klersy C. In-vitro fluoride release rates from 9 orthodontic bonding adhesives. Am J Orthod Dentofacial Orthop 2007;132:656-662.

10. Kielbassa AM, Schulte-Monting J, Garcia-Godoy F, Meyer-Lueckel H. Initial in situ secondary caries formation: effect of various fluoride-containing restorative materials. Oper Dent 2003;28:765772.

11. Okuyama K, Murata Y, Pereira PN, Miguez PA, Komatsu H, Sano $\mathrm{H}$. Fluoride release and uptake by various dental materials after fluoride application. Am J Dent 2006;19:123-127.

12. Wheeler AW, Foley TF, Mamandras A. Comparison of fluoride release protocols for in vitro testing of 3 orthodontic adhesives. Am J Orthod Dentofacial Orthop 2002;121:301-309.

13. Caves GR, Millett DT, Creanor SL, Foye RH, Gilmour WH. Fluo- ride release from orthodontic band cements-a comparison of two in vitro models. J Dent 2003;31:19-24.

14. Creanor SL, Al-Harthy NS, Gilmour WH, Foye RH, Rogers I, Millett DT. Fluoride release from orthodontic cements-effect of specimen surface area and depth. J Dent 2003;31:25-32.

15. DeSchepper EJ, Berry EA, Cailleteau JG, Tate WH. Fluoride release from light-cured liners. Am J Dent 1990;3:97-100.

16. Forss H, Seppa L. Prevention of enamel demineralization adjacent to glass ionomer filling materials. Scand J Dent Res 1990;98:173178.

17. Dijkman GE, de Vries J, Lodding A, Arends J. Long-term fluoride release of visible light-activated composites in vitro: a correlation with in situ demineralisation data. Caries Res 1993;27:117-123.

18. Itota T, Carrick TE, Yoshiyama M, McCabe JF. Fluoride release and recharge in giomer, compomer and resin composite. Dent Mater 2004;20:789-795.

19. Xu X, Burgess JO. Compressive strength, fluoride release and recharge of fluoride-releasing materials. Biomaterials 2003;24:2451-2461.

20. Hallgren A, Oliveby A, Twetman S. Salivary fluoride concentrations in children with glass ionomer cemented orthodontic appliances. Caries Res 1990;24:239-241

Accepted December 4, 2009 